\title{
Corporate Governance and Bank Performance in Nigeria: Further Evidence from Nigeria
}

\author{
Adewale Atanda Oyerinde ${ }^{1}$ \\ ${ }^{1}$ Obafemi Awolowo University, Nigera \\ Correspondence: Adewale Atanda Oyerinde, Obafemi Awolowo University, Nigera. E-mail: \\ oyerinde_adewale@yahoo.com \\ Received: April 4, 2014 \\ Accepted: June 12, 2014 \\ Online Published: July 25, 2014 \\ doi:10.5539/ijbm.v9n8p133 \\ URL: http://dx.doi.org/10.5539/ijbm.v9n8p133
}

\begin{abstract}
The paper examines the extent to which corporate governance contributed to financial crisis in the Nigerian banking industry between the periods 2000 and 2010. Panel data on post consolidated banks in Nigeria for the pre and post 2004 consolidation reforms were used. Two measures of bank performance (return on equity and net interest income) were used as dependant variable on a model that included both number of board members and related insider loans as measures of corporate governance. It was found that while size of board was significant positive insider loan is negatively related to bank performance. The paper concludes that insider loan was the most detrimental consequence of lack of corporate governance in the Nigeria banking industry. The issue raised in some studies about the size of the board members, this paper found a relatively higher number of board members to be more performance enhancing and aiding effective coordination of banks operating within the peculiarity of Nigerian financial system
\end{abstract}

Keywords: corporate governance, bank performance, Nigerian financial system

\section{Introduction}

Issues of corporate governance and corporate financial management of firms has dominated the literature on banking sectors in recent times, the crux of this paper is also to examine the Nigerian banking industry case by examining the role of corporate governance in the recent financial crises in Nigeria. The crises led to the introduction several financial reforms that culminated to the reduction in number of banks from 89 to 20 between 2004 and 2009. During the period 2000 and 2009, Nigerian banking industry experienced significance restructuring and direct intervention by the monetary authority in recent times. Among such direct intention and regulation was the introduction of corporate governance. This guideline and regulatory frameworks were put in place with the primary objective of ensuring financial operational efficiency in the financial industry. Many commentators and economic analysts as well as central bank officials have attributed to the 2008 bank failure to the lack of corporate governance. Yet there was little attempt (if any) to empirically examine contribution of purported lack of corporate governance to the crisis in the literature. This neglect and the overzealousness of public commentators as well as regulatory official to passed judgement without sound empirical basis might undermine the entrepreneurial spirit in the financial system.

This attempt of re-examining the nexus between corporate governance and bank performance in Nigeria can be justified in several ways. First studies (like Handley-Schachler et al., 2001; Adams \& Mehran, 2003) argued that while other sectors of the economy has benefited from array of studies, issues relating to corporate governance in banking industry is greatly ignored in previous research and even those that attempted the issue hardly provide any clear cut conclusion on corporate governance/performance nexus in the banking industry. Secondly, Alexander (2006) and Morgan (2002) also observed that lack of corporate governance in banks might have played a significant role US's 1980 saving and loans crisis and later 2000s subprime mortgage loan crisis as well as the Asian financial crisis in the 90s. The recent crisis in Nigerian banking industry where over 10 out of 25 banks recapitalized in 2004 failed the bank distress test underline the need to reexamine the nexus between corporate governance and performance nexus in the Nigerian banking environment. Therefore, there is possibility that corporate governance could have played a role in 2008 and 2010 financial crisis experience in Nigerian banking industry. More so, the evidence from the literature has not been so emphatic on the role played by corporate governance on bank performance. For instance, Simpson and Gleason (1999) established that there 
was no sufficient evidence to attribute bank failure to the structure of bank's board members and Prowse (1997) argues that most of the corporate governance guidelines are externally imposed by regulatory authority and might have stifled their operational initiatives. The paper is divided into five main sections. Section 2 reviews theoretical and empirical studies on corporate governance in the banking industry across countries. Section 3 discusses the analytical approaches adopted and the empirical results are discussed in section 4 while the conclusion and policy implications are presented in section 5.

\section{Literature Review}

A critical issue in the discussion of financial crisis in Nigeria is bank compliance with corporate governance guidelines. The emphasis on corporate governance in the banking industry according to Carse (2000) is based on the fact that use much of the depositors money than the shareholder's fund therefore any crisis in the banking sector affect not only the shareholders but also the creditors and depositors. Therefore, it is important to ensure that banks are operating properly. Carse (2000) also emphasised that bank should be made to comply strictly with the corporate governance for banks. The paper argued that the success of Hong Kong banks might not be unconnected with the strong and strict adherence to these set of rules.

Analyzing the relationship between corporate governance and bank performance has always been carried out using the concept of principal and agent relationship. The principal/agency conceptual approach is based on agency. The theory suggests that better governance should lead to strong relationship between corporate governance and accounting outcomes and performance by banks. Jensen and Meckling (1976) pioneered the first attempted to test this hypothesis and the outcome of the study showed that strong corporate governance leads to better performance and accounting outcomes. Tsui \& Gul, 2000; Printeris, (2002), Polo (2007) also examined similar issue with focus on board independence and stock return and total accruals. Larcker et al. (2007) adopted principal component analysis to establish a strong relationship between measure corporate governance structure and both performance and accounting outcomes.

A good number of studies have also examined the role insider information have played on the accounting outcomes and firm performance. However, Yeboah-Duah (1993) among others studies (Note 1) reported conflicting and mixed results in relation to the insider information and firm performance especially in the banking industry. For instance, McConnell and Servaes (1990) argued that the relationship between insider ownership and firm performance is not as simple as depicted by agency theory rather a nonlinear relationship only exist. In another study, Nor et al. (1999) also showed that there was a non-linear relationship between inider information and performance which is also in contract with the outcome of Yeboah-Duah (1993) and Loderer and Martin (1997) could not establish any such relationship. This implies that there is certain level at which too much or too little insider information may be harmful to firm performance.

Another issue in corporate governance is the composition of board members. Weisbach, (1988), John and Senbet (1998), Mehran (1995), Pinteris (2002), Hermalin and Weisbach (1991) established that the determining the appropriate size of the board could help in resolving the agency problem in corporate governance. According to these studies, an appropriate combination of outside directors with insider directors has strong positive effect on efficiency and effectiveness of the board of directors and consequently on the firm performance. in a survey The significant relationship between the board composition and firm performance has not gone unchallenged, Some studies (Bhagat \& Black, 1999, 2002; Hermalin \& Weisbach, 1991; Yermack, 1996; Metrick \& Ishii, 2002) have provided evidence to show that there is no of a significant relationship between firm performance and board composition especially the proportion of outside directors on the board.

This brief review showed that there are still no consensus in the literature on the relationship between corporate governance and firm performance. The main essence of this study is to contribute to this growing literature and to provide the evidence with respect to Nigeria. The Nigeria experience is unique. The banking industry in Nigeria has experienced several policy reforms and the sector had been affected both positively and negatively. The introduction of corporate guidelines by the central bank of Nigeria showed that the monetary authority has believed that corporate governance might contribute to the financial crisis experienced in 2005 to 2008 . The lack of specific empirical studies on the relationship between the corporate governance and bank performance further served the greater impetus to re-examine this issue with data from Nigeria.

\section{Empirical Methodology}

\subsection{Analytical Model and Method of Data Analysis}

The empirical analysis in this paper is based on panel data analysis. Data from 24 banks for 2001 to 2010 were sampled. Following the standard practice in the literature, the empirical relationship between the variables is 
specified as:

$$
B P_{i t}=\alpha_{i}+b_{i} C G_{i t}+c_{i} Z_{i t}+\varepsilon_{i t} ; \quad i=1,2,3 \ldots N ; \quad t=1,2,3, \ldots \ldots \ldots T
$$

Where: $B P_{i t}=$ Bank performance and $C G_{i t}=$ corporate governance. $Z_{i t}=$ other variables that may affect bank performance, $a_{i}$ is the intercept of the model while $b_{i}$ and $c_{i}=$ parameter coefficient of corporate governance and controlling variables respectively. $\varepsilon_{i}$ is an error term.

\subsubsection{The Hausman Test}

The Hausman test (also called the Wu-Hausman test) is a statistical hypothesis test in econometrics named after James Durbin, De-Min Wu and Jerry A. Hausman. The test evaluates the significance of an estimator versus an alternative estimator. It helps one evaluate if a statistical model corresponds to the data.

Consider the linear model $y=b X+e$, where $\mathrm{y}$ is the dependent variable and $\mathrm{X}$ is vector of regressors, $\mathrm{b}$ is a vector of coefficients and $e$ is the error term. We have two estimators for $b: b_{0}$ and $b_{1}$. Under the null hypothesis, both of these estimators are consistent, but $b_{1}$ is efficient (has the smallest asymptotic variance), at least in the class of estimators containing $b_{0}$. Under the alternative hypothesis, $b_{0}$ is consistent, whereas $b_{1}$ isn't.

If we reject the null hypothesis, it means that $b_{1}$ is inconsistent. This test can be used to check for the endogeneity of a variable (by comparing instrumental variable) estimates to ordinary least squares (OLS) estimates). It can also be used to check the validity of extra instruments by comparing estimates using a full set of instruments. Estimates that use a proper subset of a series. Note that in order for the test to work in any case, we must be certain of the validity of the subset of the series and that subset must have enough instruments to identify the parameters of the equation.

Hausman also showed that the covariance between an efficient estimator and the difference of an efficient and inefficient estimator is zero and thus the reason for its use in this study.

\subsection{Data Description and Sources}

Two key set of variables are of interest in this paper; the measures of banks performance and corporate governance. There is several measure of bank performance but in this paper return on equity and net interest income is used while the board size and insider loan proportion are used to capture the effects of corporate governance. The choice is based on the fact that these measures were the most frequently used in the literature and has been found to adequate for capturing corporate governance mechanism in Nigeria. The specific ways the variables are measured as explained in table 1 below:

Table 1. Definition of variables

\begin{tabular}{lll}
\hline \multirow{2}{*}{ Bank Performance } & Variables & Formula \\
& ROE & Net income/ Total equity \\
& Efficiency of interest management(EIY) & Interest income - Interest expenses/ Total assets \\
\hline \multirow{2}{*}{ Corporate Governance } & Board of directors size(BDS) & Total number of members within the board of directors \\
& Level of related-party loans(INSIDER) & Loan to related party/Net value of Bank \\
\hline \multirow{2}{*}{ Controlling Variables } & Market share of debt (MSD & Bank's total debt issues/ Total debt issue industry \\
& Nonperforming Loan(NPL) & ratio of non-performing loan to total loans \\
& Market-to-Book ratio (MBV) & Share price/Book value per share \\
\hline
\end{tabular}

Source: Author's compilation.

The population consists of all the 89 banks in Nigeria as at 2004. The sample was made up of only the $75(84 \%)$ out of the 89 banks that consolidated to form the 24 banks in existence as at 2010 . The remaining $14(16 \%)$ could not consolidate and were liquidated. Out of this 75 , only $6(8 \%)$ did not combine in any form with any other banks while 69 (92\%) fused into one another to form 18(76\%) of the final 24 banks that are now in existence after consolidation. This study employed secondary methods of data collection. Some of the banks did not provide all the necessary statistics from the base period 2000, to the lead period 2010, the data were sourced from the annual returns of these banks to Central bank of Nigeria (CBN), the Nigerian Deposit and insurance Corporation (NDIC) and the Nigerian Stock Exchange (NSE).

\section{Empirical Analysis and Results}

The results of the panel analysis for the two measures of performance were tabulated in table 2 and Table 3 . Table the reports the estimates for the return on equity while Table 3 reports estimates for the net interest income 
model. In the two estimations, the regression results for the pool, random and fixed effects models were presented. The Haussmann tests and redundancy fixed effects for checking if the individual unobserved characteristics in both cross section and period are significantly correlated are reported in the table. According to Ann and Moon (2001), the Haussmann test statistics can be viewed as a distance measure between the random and fixed effect estimators. based on the results of the tests, the two tests show that though the null hypothesis of redundant fixed effect in all the two models were rejected, the Haussmann test failed to reject that there is no significant variation between the random effect model and fixed effect model. Hence the random effect model is efficient and consistent. The ROE model estimation show that board size has significant positive effect of the performance of the bank but the insider loan measure of corporate governance had negative and significant effects. As observed from also, non-performing loan and market share ratio to debt had a significant positive relationship with ROE at one per cent.

Using net interest income as a measure of bank performance, there results are substantially different to what obtained when return on equity was used. The R-square, $\mathrm{F}$ statistics and the individual coefficient are remarkably lower and some variables were not significant. The possible explanation of this is that the return on equity could be a better measure of performance than the interest income. Since there other sources of revenue and profitability. In Nigerian many banks engage in several non-conventional activities through which they augment their interest revenue so using the interest income as a parameter to gauge their performance may underestimate the performance indices. Even at this shortcoming, the corporate governance variable was still negative and significant. The board size was not significant while both non-performing loans and market to book value were also positive but significant.

Table 2. Estimates of results for corporate governance's effects on bank performance

\begin{tabular}{llll}
\hline \multirow{2}{*}{ Independent Variables } & \multicolumn{2}{l}{ Dependent Variable (ROE) } & \\
\cline { 2 - 4 } & Pooled Model & Radom Effects & Fixed Effects \\
\hline BDS & $0.668[5.248]$ & $0.725[5.314]$ & $0.790[5.137]$ \\
INSIDER & $-2.474[-7.245]$ & $-2.394[-6.212]$ & $-2.229[-4.772]$ \\
MSV & $-0.466[-4.945]$ & $-0.493[-4.552]$ & $-0.655[-2.762]$ \\
MSD & $1.191[4.445]$ & $1.276[4.416]$ & $1.492[4.460]$ \\
NPL & $1.661[11.716]$ & $1.706[12.189]$ & $1.755[11.772]$ \\
C & $-0.766[-5.858]$ & $-0.648[-4.963]$ & $-0.890[-4.835]$ \\
Adj.R ${ }^{2}$ & 0.5912 & 0.581 & 0.722 \\
F-Stat & $50.450[0.000]$ & $50.513[0.000]$ & $11.955[0.000]$ \\
\hline Random Hausman Test & & Chi-Sq. (Prob) & \\
\hline Cross-section random & & $0.47065(0.99)$ & \\
Period random & & $4.221(0.51)$ & \\
Cross-section and period random & $3.570(0.612)$ & \\
\hline Redundant Fixed Effect Test & & & $2.89(0.000)$ \\
\hline Cross-section F & & & $57.27(0.000)$ \\
Cross-section Chi-square & & & $1.96(0.000)$ \\
Period F & & & $18.26(0.000)$ \\
Period Chi-square & & & $2.56(0.000)$ \\
Cross-Section/Period F & & & $69.42(0.000)$ \\
Cross-Section/Period Chi-square & & & \\
\hline
\end{tabular}


Table 3. Estimates of results for corporate governance's effects on bank performance

\begin{tabular}{llll}
\hline \multirow{2}{*}{ Independent Variables } & \multicolumn{2}{l}{ Dependent Variable (EIY) } & \\
\cline { 2 - 4 } & Pooled Model & Radom Effects & Fixed Effects \\
\hline BDS & $0.059[1.071]$ & $0.084[1.465]$ & $0.111[1.701]$ \\
INSIDER & $-0.389[-2.685]$ & $-0.313[-1.920]$ & $-0.200[-0.009]$ \\
MSV & $-.0534[-1.358]$ & $0.070[-1.282]$ & $-0.123[-1.221]$ \\
MSD & $0.276[2.425]$ & $0.317[2.590]$ & $0.380[2.674]$ \\
NPL & $0.252[4.189]$ & $0.255[4.306]$ & $0.258[4.065]$ \\
C & $0.428[7.506]$ & $0.401[5.235]$ & $0.384[4.901]$ \\
Adj.R ${ }^{2}$ & 0.256 & 0.276 & 0.423 \\
F & $6.143[0.000]$ & $6.239[0.000]$ & $3.368[0.000]$ \\
\hline Random Hausman Test & & & \\
\hline Cross-section random & & $1.910(0.861)$ & \\
Period random & & $2.130(0.831)$ & \\
Cross-section and period random & & $2.457(0.783)$ & \\
\hline Redundant Fixed Effect Test & & \\
\hline Cross-section F & & & $2.613(0.000)$ \\
Cross-section Chi-square & & $52.387(0.000)$ \\
Period F & & & $2.541(0.0000)$ \\
Period Chi-square & & $23.319(0.000)$ \\
Cross-Section/Period F & & $2.577(0.000)$ \\
Cross-Section/Period Chi-square & & $69.764(0.000)$ \\
\hline
\end{tabular}

\section{Conclusion and Policy Implication}

The paper concludes that regulatory forces within the banks in the Nigerian economy were not effective in promoting a safe and fair allocation of bank resources necessary to prevent the banking sector from crisis experienced after the global financial crisis. The significant relationship observed between corporate governance and bank performance is consistent Simpson and Gleason (1999), which observed that there is relationship between the structure of banks' board of directors and subsequent bank failure (Hugh, 2009). The implication of the above is that weak corporate governance was a contributing factor to the poor performance of banks

The policy implication is that Central Nigerian Bank has to encourage banks to embrace good corporate governance practices through enacting rules and regulations. Good corporate governance practices will ensure that banks maintain the level of risk they can handle and give depositors sufficiently safe level of their savings and investments. Several regulations encouraging corporate governance practices are: legal lending limits, the quality of assets, knowledge of your customers' rules, protection rules against money laundering, etc. Given the positive effect of the size of board director on bank performance, there is the need to encourage a relative bigger size. This allow for robust and thought through process in decision making. In the case where the board member is small, here is tendency for the few people to dominate and influence decision even at the detriment of the organisation. This is because the board of directors is a collective of people who are responsible for approving the strategy and business plan of the bank. Therefore, the existence of a moderately big size -efficient board of directors is necessary to coordinate the conflict between shareholders and managers, and consequently improve banks' performance.

The negative impact of related party-loan on return on equity simply indicates that higher levels of related-party loans are expected to adversely affect the bank's performance and higher exposure to related-party loans will raise the probability of loan impairment and adversely affect the ROA of banks (Christopher, 2009). Therefore to ensure improved bank performance, related-party loan should reduce significantly and any related-party loan given should be backed with appropriate collateral. Also, the central bank should ensure the appropriateness of checks and balances, accountability and transparency in the board of directors constituting the governing entity.

\section{References}

Adams, R., \& Mehran, H. (2003). Is Corporate Governance Different for Bank Holding Companies? Economic Policy Review, 123-142. http://dx.doi.org/10.2307/2331397

Agrawal, A., \& Knoeber, C. R. (1996). Firm Performance and Mechanisms to Control Agency Problems between Managers and Shareholders. The Journal of Financial and Quantitative Analysis, 31(3), 377-397. 
Alexander, K. (2006). Corporate Governance and Banks: The Role of Regulation in Reducing the Principal-agent Problem. Journal of Banking Regulation, 7, 17-40. http://dx.doi.org/10.1057/palgrave.jbr.2340003

Ann, S. C., \& Moon, H. R. (2001). Large N and Large T Properties of Panel Data Estimators and the Haussmann Test August 2001 USC CLEO Research Paper No C01-20.

Bhagat, S., \& Black, B. (1999). The uncertain relationship between board composition and firm performance. The Business Lawyer, 54(3), 921-963.

Bhagat, S., \& Black, B. (2002). The Non-correlation between Board Independence and Long-term Firm Performance. The Journal of Corporation Law, 27(2), 231.

Bicksler, J. M. (2008). The Subprime Mortgage Debacle and its Linkage to Corporate Governance. International Journal of Disclosure and Governance, 5, 296-300. http://dx.doi.org/10.1057/jdg.2008.20

Carse, D. (2000). Speech: The importance of corporate governance in banks. Retrieved May 7, 2009, from http://www.info.gov.hk/hkma/eng/speeches/speechs/david/20000317.htm

Coffee, J. (1991). Liquidity versus Control: The Institutional Investor as Corporate Monitor. Columbia Law Review, 91, 1277-1368. http://dx.doi.org/10.2307/1123064

Core, J. E., Holthausen, R. W., \& Larcker, D. F. (1999). Corporate Governance, Chief Executive Officer Compensation, and Firm Performance. Journal of Financial Economics, 51, 371-406. http://dx.doi.org/10.1016/S0304-405X(98)00058-0

De Angelo, H., \& De Angelo, L. (1985). Managerial Ownership of Voting Rights: A Study of Public Corporations with Dual Classes of Common Stock, Journal of Financial Economics, 14, 33-69. http://dx.doi.org/10.1016/0304-405X(85)90043-1

Estrin, S. J., Konings, Z. Z., \& Angelucci, M. (2001). The effect of ownership and competitive pressure on firm performance in transition countries: Micro evidence from Bulgaria, Romania and Poland. Paper presented at LICOS, K.U. Leuven; a Phare Ace workshop on Competition Policy in Romania, 7 August.

Fosberg, R. (1989). Outside Directors and Managerial Monitoring. Akron Business and Economic Review, 20(2), 24.

Handley-Schachler, M., Juleff, L., \& Paton, C. (2001). Corporate governance in the Financial Services Sector. Corporate Governance, 7, 623-634. http://dx.doi.org/10.1108/14720700710827202

Hermalin, B. E., \& Weisbach, M. S. (1991). The effects of board composition and direct incentives on firm performance. Financial Management, 20(4), 101. http://dx.doi.org/10.2307/3665716

Hermalin, B. E., \& Weisbach, M. S. (2003). Boards of Directors as an Endogenously Determined Institution: A Survey of the Economic Literature. Economic Policy Review, 12, 7-26.

Holderness, C. G., \& Sheehan, D. P. (1988). The Role of Majority Shareholders in Publicly Held Corporations: An Exploratory Analysis. Journal of Financial Economics, 20, 317-346. http://dx.doi.org/10.1016/0304-405X(88)90049-9

Jensen, M. C., \& Meckling, W. H. (1976). Theory of the firm: Managerial behavior, agency costs and ownership $\begin{array}{llll}\text { structure. Journal of } & \text { Financial 305-360. }\end{array}$ http://dx.doi.org/10.1016/0304-405X(76)90026-X

John, K., \& Senbet, L. W. (1998). Corporate governance and board effectiveness. Journal of Banking and Finance, 22, 371-403. http://dx.doi.org/10.1016/S0378-4266(98)00005-3

La porta, R., Lopez-De-Silanes, F., Shleifer, A., \& Vishny, R. (2002). Investor Protection and Corporate Valuation. The Journal of Finance, 57(3), 1147-1170. http://dx.doi.org/10.1111/1540-6261.00457

Larcker, D. F., Richardson, S. A., \& Tuna, I. (2007). Corporate Governance, Accounting Outcomes, and Organizational Performance. The Accounting Review, 82, 963-1008. http://dx.doi.org/10.2308/accr.2007.82.4.963

Lipton, M., \& Lorsch, J. W. (1992). A Modest Proposal for Improved Corporate Governance. The Business Lawyer, 48(1), 59.

Loderer, C., \& Martin, K. (1997). Executive Stock Ownership and Performance Tracking Faint Traces. Journal of Financial Economics, 45(2), 223-255. http://dx.doi.org/10.1016/S0304-405X(97)00017-2 
McConnell, J. J., \& Servaes, H. (1990). Additional Evidence on Equity Ownership and Corporate Value. Journal of Financial Economics, 27(2), 595-612. http://dx.doi.org/10.1016/0304-405X(90)90069-C

Mehran, H. (1995). Executive compensation structure, ownership and firm performance. Journal of Financial Economics, 38, 163-84. http://dx.doi.org/10.1016/0304-405X(94)00809-F

Metrick, A., \& Ishii, J. (2002). Firm-level corporate governance. Paper presented at Global Corporate Governance Forum Research Network Meeting, Washington, D.C.

Mintz, S. M. (2005). Corporate Governance in an International Context: Legal Systems, Financing Patterns and $\begin{array}{lllll}\text { Cultural Variables. } & \text { Corporate } & \text { Governance, } & 13,\end{array}$ http://dx.doi.org/10.1111/j.1467-8683.2005.00453.x

Monks, R. A. G., \& Minow, N. (1995). Corporate governance on equity ownership and corporate value. Journal of Financial Economics, 20, 293-315.

Morck, R., Shleifer, A., \& Vishny, R. W. (1988). Management Ownership and Market Valuation: An Empirical analysis. Journal of Financial Economics, 20(1-2), 293-316. http://dx.doi.org/10.1016/0304-405X(88)90048-7

Nor, F. M., Said, R. M., \& Redzuan, H. (1999). Structure of ownership and corporate financial performance: A Malaysian case. Malaysian Management Review, 44-48.

Renneboog, L. (2000). Ownership, managerial control and governance of companies listed on the Brussels stock exchange. Journal of Banking and Finance, 24(12), 1959-1995. http://dx.doi.org/10.1016/S0378-4266(99)00128-4

Simpson, W. G., \& Gleason, A. E. (1999). Board Structure, Ownership, and Financial Distress in Banking Firms. International Review of Economics and Finance, 8, 281-292. http://dx.doi.org/10.1016/S1059-0560(99)00026-X

Weisbach, M. (1988). Outside directors and CEO turnover. Journal of Financial Economics, 20, 431-60. http://dx.doi.org/10.1016/0304-405X(88)90053-0

Yeboah-Duah, K. (1993). Stock ownership and the performance of the firm in Malaysia. Capital Market Review, l(2), 83-108.

Yermack, D. (1996). Higher Market Valuation of Companies with a Small Board of Directors. Journal of Financial Economics, 40(2), 185-211. http://dx.doi.org/10.1016/0304-405X(95)00844-5

\section{Note}

Note 1. Other studies include DeAngelo and DeAngelo, (1985), McConnell and Servaes (1990), Loderer and Martin (1997), Nor et al (1999).

\section{Copyrights}

Copyright for this article is retained by the author(s), with first publication rights granted to the journal.

This is an open-access article distributed under the terms and conditions of the Creative Commons Attribution license (http://creativecommons.org/licenses/by/3.0/). 